\title{
MODELING SOCIO-ECOLOGICAL STRUCTURE OF LOCAL COMMUNITIES PARTICIPATION FOR MANAGING LIVESTOCK DRINKING WATER USING THE AGENT-BASED APPROACH
}

\author{
ISLAMI, I. ${ }^{1}$ - SADODDIN, A. ${ }^{1 *}$ - BARANI, H. ${ }^{1}-$ ASGHARPOURMASOULEH, A. $^{2}-$ \\ AKHBARI, M. ${ }^{3}$ \\ ${ }^{1}$ Gorgan University of Agricultural Sciences and Natural Resources \\ Basij Sq., Gorgan, Golestan Province, Iran. \\ e-mail:im_islami@yahoo.com; phone: +98-913-1592606 \\ ${ }^{2}$ Ferdowsi University of Mashhad \\ Azadi Sq., Mashhad, Khorasan Razavi, Iran. \\ phonelfax: +98-513-8805198 \\ ${ }^{3}$ Colorado Water Institute \\ Fort Collins, CO 80523-1033, USA. \\ phonelfax: +970-412-3088 \\ *Corresponding author \\ e-mail: amir.sadoddin@gmail.com; phone: +98-173-2436408; fax:+98-173-4424155
}

(Received $9^{\text {th }}$ Nov 2016; accepted $28^{\text {th }}$ Mar 2017)

\begin{abstract}
The agent-based modelling ( $\mathrm{ABM}$ ) can illuminate how multi-dimensional process of public participation emerges from simple behavior rules. It can model the participation process which is too complicated using congenital approaches. In the present research, the social structure of human participation in managing livestock drinking water of arid rangelands in Yazd Province, Iran, was designed using the four steps of ABM. This study provides a true understanding of interactions of four agents including government, livestock beneficiaries, natural resources organization and NGOs with each other and with the natural environment. In order to achieve conceptual proof, the Delphi technique was applied for stepwise identification of agents and their real behaviors. Additionally, quantification of decision elements and decision-making hypotheses was examined using the Analytical Network Process (ANP). By confirming the conceptual validity of decision-making hypotheses through network analysis, the conceptual model was confirmed. The analysis demonstrates that "low income of livestock beneficiaries", "successive droughts and low rainfall" and "weakness of NGOs", with normal weights of $0.31,0.15$, and 0.09 , respectively are three major drivers for problem of weak participation among local communities in the study area. This research is an example of incorporating the ABM approach in settling problems encountered with social system.
\end{abstract}

Keywords: Local Participation, Agent-Based Modeling (ABM), Delphi technique, Analytical Network Process (ANP).

\section{Introduction}

Rangelands, livestock and humans constitute three sides of a triangle which makes up the rural livelihood of a rancher in dry ecosystems. In arid rangelands of Iran particularly in Yazd province in geographically central plateau of Iran, high temperature, salinity, water scarcity and inappropriate distribution of water resources are among major problems of ranchers in livestock breeding. This situation which has been worsened by occurring droughts has incurred more than 232 billion rials damage to the rangeland of this province that has been unprecedented over the past 10 years (MENARID, 2015). Due to drought and lack of drinking water for livestock in the 
rangelands of this province, 60 percent of rangelands have been unusable (MENARID, 2015). Water resources development along with more uniform utilization of all rangelands' forage, the possibility of grazing in other parts of rangelands and increased grazing period allow the ranchers to increase the number of their livestock (Azarnivand and Zare Chahoki, 2008). In 2004, one billion head of sheep were dependent on the rangelands of Yazd province which as a result of successive droughts in recent years, this number has been decreased to 400 thousand head of livestock in 2014. Moreover, the number of families that earn their livelihood by livestock breeding has been reduced to about 5 thousands households in 2014 (MENARID, 2015). Recently, the need of participation of all the stakeholders, beneficiaries and relevant organizations to provide and develop the water resources required by livestock in rangelands has become a "social" in this province. (Keshavarz et al., 2013; Semsaryazdi and Labbafkhaneiki, 2007). Studies show that failure of public participation projects in supplying the required drinking water of ranchers and developing this resource in different countries has often various social and economic effects on the structure of local community of herders and ranchers. These consequences include forced early selling of livestock and its financial costs, expansion of local conflicts, local communities empty of inhabitants and poverty. (e.g. Turner et al., 2004; Meier et al., 2007; Francis et al., 2011; Selby and Hoffmann 2014). Completed studies done in this province has emphasised on the need for collaborative solutions in the utilization of the capacity of local communities in water resource management and development for livestock drinking purpose (e.g. Piran, 2005; Semsaryazdi and Labbabkhaneiki, 2007; Islami et al., 2013). Apart from the drought effects, a wide range of economic and social factors has influenced on the public participation. Many researchers have focused on the impact of individual characteristics, including age, gender, education, household size, costs, incomes and ownership (e.g. O'Faircheallaigh, 2010). However, some others have talked about the role of knowledge and information and factors such as extension courses and proper information system (e.g. Bond, 2014). Some have mentioned the role of attitude and its impact on participation. They believe that positive attitude of an individual towards an issue or a plan can increase his/her involvement in the project implementation (e.g. Rishi, 2003; Vicente and Reis, 2008). A few of researchers have noted the role of social concepts and theories, such as social discrimination, social distance, social influence and social trust as the factors influencing participation in the natural resources sector (e.g. Piran, 2005; Arnold and Gimenez, 2007; Islami and Abdollahian, 2016). For example the Social Network Analysis (SNA) of livestock beneficiaries of yazd province indicate the poor participation of local ranchers, as well as weak stability of the network of these beneficiaries (Islami and Abdollahian, 2016). In this research the result of visual analysis of the social network indicates poor networks of both trust and participation in intergroup relationships of local ranchers characterised by island social structure influenced by several structural holes (Islami and Abdollahian, 2016). With regard to relevant factors in public participation it can be said that no general theory has been developed which can consist of all or most factors related to participation.

Unlike the research mentioned, the present study attemts to identify the effective and inhibiting factors of participation using an agent based system. It does so based on the identification of factors, dependences and interactive relations of these factors regarding their complexity. The use of ABM approach facilities the Understanding the complex interaction between social factors in a social phenomenon. Identifying the key actors in a form of a system; an Agent Based Model (ABM) leads to better understanding of 
social systems (Squazzoni, 2012). Over the past decades, ABM has been considered as a new and promising methodology in modeling in various disciplines especially complex social-ecological systems and social simulation (e.g. Bonabeau, 2002; Janssen, 2002; Parker et al., 2003, Bousquet and Le page, 2004; Matthews et al., 2007; Akhbari and Grigg, 2013; Wilensky and Rand, 2015). Popularity of ABM can be due to high potential of this model in solving the problems of the real world and also due to overcoming the traditional problem of sociology (point to lack of appropriate methods and tools to understand the social structure of society) (e.g. Janssen, 2002; Bousquet and Le Page, 2004; Macy and Willer, 2002; Gilbert and Troitzsch, 2005; Squazzoni, 2012; Akhbari and Grigg, 2015). However this does not mean that this model is perfect and there is no ambiguity in its method and structure. Various researchers in agent based modeling approach have spoken of three ambiguities that must be clarified. These include: 1) conceptual proof: the ABM should address both theoretical and empirical issues (Janssen and Ostrom, 2006), 2) Developing behaviorally realistic agents: the shift from simple behavioral rules to more complex decisions making processes with theoretical and empirical bases (Jager and Janssen, 2002; Mosler and Tobias 2005; Knoeri et al, 2011), 3) Validation of conceptual model: conceptual model validation is defined as "determining that the theories and assumptions underlying the conceptual model are correct and that the model representation of the problem entity is 'reasonable' for the intended purpose of the modeling" (Sargent, 2008). In particular, there are highlighted weaknesses in the sociological researches: 1) the need for real clarification of a problem, 2) identifying contributing agents and behaviors on the basis of a specific methodology.

The present research attempts to compensate the weaknesses in the most fundamental part of an agent-based modeling i.e. identifying agents, behavioral rules and their interactions. It also tries to give convincing answers to the above questions. The aim of this research is to identify system key agents and their characteristics, interactions and rules of behavior. Eventually, by providing a conceptual model of social structure of public participation, this research deals with the real pathology for inadequate participation of local communities in developing water resources for livestock drinking in Yazd Province as one of the most prominent arid and desert ecosystems in Iran. This paper explains how the complex and multidimensional phenomenon of participation can be made out of simple rules of behavior and decision making.

\section{Materials and Methods}

In order to design socio-ecological structure of human participation based on an agent-based model, in this research an agent operationalization approach, suggested by Knoeri et al. (2011), has been reformulated. This approach has provided based on the conceptual framework of the Giddens' structuration theory. The Giddens' structuration theory is one of the several theories of social processes (Cedermann, 2005) and has focused on how the social structure is made out of human activity (Binder, 2007). Four implementation steps of this approach after defining the problem as their prerequisite include 1) to identify agents and relevant behaviors; 2) to analyze agents' interactions, 3 ) to quantify agents' decision making process and 4) to analyze conceptual validity.

This research has used different methods and techniques for doing these four steps. This section briefly describes methods of data collection and analysis. The Delphi technique was used to identify the agents and their behavior. Delphi technique has been 
established to select and combine experts' judgments on a real issue and with the primary aim of establishing an agreement between panel members (Gordon, 1992; Jeffery and Hache, 1995).

The Delphi technique was chosen in the first step to identify, structure, summarize and reach a high consensus between experts on factors influencing inadequate public participation for livestock drinking water management in the research area (Hasson et al., 2000; Sandry and Bulger, 2008). This technique was used for more than 4 months in three rounds. Steps undertaken for Delphi technique include: 1) to identify and select a group of experts in the field of research 2) to prepare and send the first questionnaire to the group of expects 3) to integrate and compile the responses in the first round 4) to revise and send second round questionnaire to expert members 5) statistical analyses of the answers received in the second round in order to get the parameters screened 6) to prepare and send the third round questionnaire to expert members and 7) statistical analysis of answers received in the third round that led to the finalization of parameters which obtained from full consensus of panel members. In this research, based on existing standards (Skulmoski et al., 2007) different criteria were established to ensure that the experts have the necessary authority, representativeness and their results are reliable. The selected members of the expert panel have over 10 years background in the specialized field, knowledge and practical experience of the raised issue and sufficient information about the area under study. They also had desire to participate in this research, enough time to work on this project, and good communication skills. While there is a significant difference in the ideal size of expert panel members for Delphi technique, the related literature suggests that it should have at least 10 members (Parente and Parente, 1987).

Sampling was done using the snowball technique as so after reaching theoretical saturation ultimately 15 participants were chosen as experts. Literature review also suggests that choosing 15 people as panel member is satisfactory (Ziglio, 1996) and increasing the number up to 25- 30 participants would make no significant changes in the result (Delbecq et al., 1975). Since selection of panel member is possible with different degrees of specialization, in this research experts specialized in various fields related to the issue and in three groups of five people were organized. Table 1 gives some information about the expert panel members participating in this research. In order to achieve more effective consensus, all the rounds were done face to face. In addition, after each round, panel members received a summary of identified parameters and individual responses feedback of all members of the panel.

Table 1. Features of the expert panel elicited through the Delphi technique

\begin{tabular}{c|c|c|c|c}
\hline $\begin{array}{c}\text { Group of the } \\
\text { expert panel }\end{array}$ & Education & Affiliation & $\begin{array}{c}\text { Experience } \\
\text { (years) }\end{array}$ & Specialized fields \\
\hline $\begin{array}{c}\text { Faculty } \\
\text { members }\end{array}$ & $\mathrm{PhD}$ & $\begin{array}{c}\text { Faculty members of range } \\
\text { management departments }\end{array}$ & $10-28$ years & $\begin{array}{c}\text { Range management } \\
\text { (reclamation and } \\
\text { development of ranges }\end{array}$ \\
\hline Executives & MSc. & $\begin{array}{c}\text { Range Extension and } \\
\text { Education Unit of Natural } \\
\text { Resources Organization - } \\
\text { Yazd Province }\end{array}$ & $15-24$ years & $\begin{array}{c}\text { Range management/ } \\
\text { extension \& education } \\
\text { of natural resource }\end{array}$ \\
\hline Local ranchers & BSc. & $\begin{array}{c}\text { Prize awarded ranchers of } \\
\text { Yazd Province during 2011- } \\
2015\end{array}$ & $17-34$ years & $\begin{array}{c}\text { Range management } \\
\text { and livestock breeding }\end{array}$ \\
\hline
\end{tabular}


Descriptive statistics such as mean, standard deviation and percentage of agreement were also shared by the panel members, to facilitate consensus achievement (Hasson et al., 2000, Keeney et al., 2006, Sandrey and Bulger, 2008). This multi-step process of questionnaire and comments feedback circulation was continued to the point of panel members consensus on the factors under investigation. In order to conduct brainstorming, in the first round using an open ended questionnaire experts' opinion has been elicited on the factors influencing poor public participation in developing livestock drinking water in Yazd rangelands. After gathering responses from the first round, panel members were asked to score the factors on a 5- level Likert scale on the basis of the theoretical preferences of the respondents and the influences of the factors on the issue. Scoring was done to determine minimum to maximum importance of the factors $(1=$ strongly disagree, $2=$ disagree, $3=$ no idea, $4=$ agree, $5=$ strongly agree) (Bugler and Housner, 2007). In order to analyze the results of the second round of Delphi, screening was performed by considering a minimum score of 3 out of 5 to detect the influencing factors on participation identified by the experts. In third round of Delphi as the final step, consensus of opinion was assessed through three strict criteria including: 1) to attain at least $75 \%$ of experts' votes on the influencing factors 2) to meet the minimum score of 4 out of 5 (mean score of comments of the three groups of expert) (Bulger and Housner, 2007), and 3) To satisfy the Kruskal-Wallis statistical test. Kruskal-Wallis test was performed to detect on which factors there is a consensus among the three groups of experts. Through these criteria, factors on which existed a consensus among the three groups of experts were placed in the final list. After identifying and finalizing the factors influencing the participation, using Delphi technique, agents were extracted from the factors. These identified factors are representatives of those behaviors shown by agents in the agent-based model.

Agents identification was done based on the homogeneity between factors and the related agent. It means that a factor is connected with a specific agent in the social environment (individuals). In other words, it should be identified which individuals, groups or social institutions are responsible for a specific factor/behavior. At the end of the first step and before proceeding to the second step of ABM, characteristics of agents and their interactions are classified to establish the framework of the ABM. The second step is the analysis of the agents' interaction chain. The purpose of this step is to design the social structure of the participation using identified agents and behaviors that is shown as a conceptual model. This step was done by interviewing the same group of experts. Having specialization and proper understanding of the social reality of the study area, experts significantly helped to achieve the modeling steps. The third step of $\mathrm{ABM}$ is to quantify agents decision making process. Among multi criteria decision making models (MCDM), Analytical Network Process (ANP), which accounts for the interdependence of parameters, was chosen to assess and prioritize finalized parameters of Delphi technique. This step was performed in two stages including: 1) developing a network of parameters' bilateral relations and 2) prioritizing the parameters'.

Data collection tools in this step included specialized interviews and pair-wise comparison questionnaires. The 1 to 9 scale for pair-wise comparison suggested by Saaty (1996) was adopted for this research and the Superdecisions software (version 2.2) was used for network analysis. The final step of ABM in this research is to evaluate the conceptual validity which was confirmed through stating various arguments in the related section. 


\section{Results and Discussion}

\section{Agents and behaviors}

The results of compiling and integrating responses obtained from the first questionnaire of Delphi along with the literature review related to the subject identified 48 parameters which were classified into three categories of social, economic and climatic criteria. Total number (100 percent) of questionnaires were returned. After initial identification of parameters in the first round, a second questionnaire with close ended questions was designed on a 5 level Likert scale to determine the approval degree of experts on parameters passed to this stage. The aim of this second questionnaire was to screen and remove low impact and non-impact parameters. Each parameter was passed to the next round, having experts minimum consensus with above average score ( 3 out of 5). The results of data analysis in second round indicated that 22 parameters including 12 parameters social criteria, 6 parameters from economic criteria and 4 parameters from climatic criteria were effective and advanced to the third round. The results showed that experts had no consensus on the effectiveness of parameters such as "low education", "inadequate supervision of the state organs", "poor role of social leadership", "low record of ranchers' participation", "poor condition of Yazd rangelands" and "lack of ecological potential of Yazd rangelands", thus these parameters were excluded in this stage. After receiving comments in the third round of Delphi, parameters resulted from second round were given to the experts in the form of a third questionnaire and their approval to the parameters was determined. The third questionnaire was aimed at reaching complete consensus on parameters. At this point strict criteria were set to determine maximum consensus to extract the final list of parameters.

The parameters were selected based on the following conditions:1) approval of at last $75 \%$ of experts on parameters, 2) obtaining score 4 out of 5 and 3) Assessing panel members consensus using the Kruskal-Wallis statistical test. As shown in Table 2, 15 parameters were selected while 7 parameters were omitted from the final list. The finalized parameters in the last stage of Delphi received the expert's consensus ranging from $76 \%$ to $90.7 \%$. Climatic parameter of "successive droughts and reduced rainfall" and social parameter of "poor performance of nongovernmental organizations", obtaining $90.7 \%$ of experts' approval and also the score of 4.53 both had the greatest influence. These parameters have been mentioned in the past basic researches in the field of participation such as Gezon (1997).

It should be noted that, the absence of coherent cooperatives in the rural communities of Yazd (weakness of social networks) is considered a major causes of poor advancement of social goals of local communities in this province (Such as not pursuing their common and legal rights). Non-governmental institutions as mediators between the government and people significantly help in this regard. The problem of "not pursuing ranchers' common and legal rights", identified and emphasized by experts, expresses the demands of people from governmental institutions. Functionalistic examination of the problem from sociological point of view shows that the decision making institutions participation in developing livestock drinking water resources has been poor. As a result, this poor performance failed to develop social cohesion among local communities for participation. The next most effective parameters are: "lack of deterrent supportive laws" and "lack of necessary pressure on governmental institutions" with $86.7 \%$ approval and "the role of capital and low income of ranchers" 
with $85.3 \%$ approval and "poor performance of promoters of natural resources" with $89 \%$ approval. The latter one has been emphasized by Bond (2014).

Table 2. Experts' consensus on different criteria and parameters influencing poor participation of beneficiaries in managing livestock drinking water in the 3rd round of Delphi

\begin{tabular}{|c|c|c|c|c|c|c|}
\hline Criteria & $\begin{array}{l}\text { Finalized parameters influencing } \\
\text { poor public participation }\end{array}$ & $\begin{array}{l}\text { Approval } \\
\text { rate }\end{array}$ & $\begin{array}{c}\text { Average } \\
\text { approval of } \\
3 \text { groups of } \\
\text { experts } \\
\text { (out of } 5 \text { ) }\end{array}$ & $\begin{array}{l}\text { Statistical } \\
\text { test }\end{array}$ & $\begin{array}{c}\text { Consensus } \\
\text { status }\end{array}$ & $\begin{array}{c}\text { Parameter } \\
\text { status }\end{array}$ \\
\hline \multirow{14}{*}{$\begin{array}{l}\text { Social } \\
\text { criteria }\end{array}$} & $\begin{array}{l}\text { Failure to pursue common and legal } \\
\text { rights of ranchers }\end{array}$ & 85.3 & 4.47 & 0.639 & $\checkmark$ & Chosen \\
\hline & $\begin{array}{c}\text { Poor performance of non- } \\
\text { governmental organization (NGOs) }\end{array}$ & 90.7 & 4.53 & 0.116 & $\checkmark$ & Chosen \\
\hline & $\begin{array}{l}\text { Low social trust between ranchers } \\
\text { community and between ranchers } \\
\text { and responsible agencies }\end{array}$ & 80 & 4 & 0.234 & $\checkmark$ & Chosen \\
\hline & $\begin{array}{l}\text { Lack of appropriate legislation and } \\
\text { push for new legislations }\end{array}$ & 86.7 & 4.33 & 0.962 & $\checkmark$ & Chosen \\
\hline & Poor performance of promoters & 84 & 4.2 & 0.769 & $\checkmark$ & Chosen \\
\hline & $\begin{array}{l}\text { Poor tendency to participate and } \\
\text { lack of inspiring motivation }\end{array}$ & 78.7 & 4 & 0.865 & $\checkmark$ & Chosen \\
\hline & Lack of deterrent penalties & 78.3 & 4.53 & 0.732 & $\checkmark$ & Chosen \\
\hline & Ranchers' violations and conflicts & 77.8 & 4.07 & 0.356 & $\checkmark$ & Chosen \\
\hline & Range lands management styles & 77.3 & 4 & 0.522 & $\checkmark$ & Chosen \\
\hline & $\begin{array}{l}\text { Water resources development } \\
\text { (support action) }\end{array}$ & 77.3 & 4 & 0.660 & $\checkmark$ & Chosen \\
\hline & $\begin{array}{l}\text { People's belief in private ownership } \\
\text { rather than shared ownership }\end{array}$ & 72 & 3.6 & 0.005 & $x$ & Removed \\
\hline & $\begin{array}{c}\text { Not incorporating beneficiaries' } \\
\text { ideas in preparing participatory } \\
\text { plans }\end{array}$ & 72 & 3.6 & 0.023 & $x$ & Removed \\
\hline & $\begin{array}{c}\text { Negative attitude towards } \\
\text { participating }\end{array}$ & 70.7 & 3.5 & 0.011 & $x$ & Removed \\
\hline & $\begin{array}{l}\text { The impact of shared beneficiary } \\
\text { system of rangelands }\end{array}$ & 68 & 3.4 & 0.000 & $x$ & Removed \\
\hline \multirow{2}{*}{$\begin{array}{l}\text { Climatic } \\
\text { criteria }\end{array}$} & $\begin{array}{l}\text { Successive droughts and reduced } \\
\text { rainfall }\end{array}$ & 90.7 & 4.53 & 0.212 & $\checkmark$ & Chosen \\
\hline & $\begin{array}{l}\text { Inadequate distribution of water } \\
\text { resources in rangelands }\end{array}$ & 76 & 4.13 & 0.441 & $\checkmark$ & Chosen \\
\hline \multirow{3}{*}{$\begin{array}{l}\text { Economic } \\
\text { criteria }\end{array}$} & $\begin{array}{l}\text { Low and inadequate income of } \\
\text { ranchers }\end{array}$ & 85.3 & 4.53 & 0.301 & $\checkmark$ & Chosen \\
\hline & $\begin{array}{l}\text { Financial dependency of ranchers to } \\
\text { the government }\end{array}$ & 82.7 & 4.27 & 0.407 & $\checkmark$ & Chosen \\
\hline & $\begin{array}{l}\text { Poor performance of ranching in } \\
\text { arid rangelands }\end{array}$ & 78.7 & 4 & 0.126 & $\checkmark$ & Chosen \\
\hline
\end{tabular}




\begin{tabular}{c|c|c|c|c|c|c}
\hline & $\begin{array}{c}\text { Non-economic rangelands } \\
\text { (disregard to the production of by } \\
\text { products) }\end{array}$ & 66.7 & 3.3 & 0.001 & $\boldsymbol{x}$ & Removed \\
\cline { 2 - 6 } & The high cost of water & 68 & 3.4 & 0.017 & $\boldsymbol{x}$ & Removed \\
\cline { 2 - 6 } & Lack of investment in range sector & 64 & 3.2 & 0.010 & $\boldsymbol{x}$ & Removed \\
\hline
\end{tabular}

According to the results, the role of "lack of encouraging motivation" that represents psychological parameters and is considered internal is known as one of the important factors. Unfortunately, the growing problem of "social conflicts" in recent years is one of the factors contributing to the breakdown of social ties in local communities of Yazd. These conflicts often occur between ranchers and miners. Trying to legislate supportive laws besides strict and preventive penalties to resolve the conflicts has been suggested by experts to solve this problem. The following points can be deduced from assessing parameters: 1) High importance of social criterion with the highest number of parameters, however, it's not the only influencing criterion and economic and climatic criteria are also effective in problem solving. 2) A very important point is that, in the social world, these parameters are performed by actors. Therefore, identifying real and key actors of the system and their interaction with each other and with the environment in the form of a system, provides a great help to solve a complex social phenomenon. The rest of this paper will answer two important questions: 1) Who are the key actors in the participatory system? And 2) Which behaviors by these actors have the greatest impact on the participatory system.

\section{Identification of the key agents from the final list of parameters}

In this part, the actors (agents) who truly represent the identified behaviors are introduced. Given the importance of this issue, the researcher discussed the finalized parameters with the expert panel, and finally got four agents. The characteristics considered for the selection of these agents include: 1) The agent has the basic characteristics of an ABM such as autonomy (self-determining) and heterogeneity and represents desired characteristics, decisions and goals. 2) The decision maker agent does that behavior in the real society and through interactions that can influence and form a phenomenon. 3) Given that this research is a social modeling, all agents have been chosen from human agents; i.e. an individual or an organization that consists of individuals.

The human agents have attributes such as potentially irrational behavior, subjective choices and complex psychology (Bonabeau, 2002). 4) In choosing the agents it has been noted that agents have the most homogeneity with the identified behavior (Macal and North, 2006b; Wilensky and Rand, 2015).

The important thing is that according to experts' judgments; the structure of the model explains the social and external reality in the area under study. Table 3 shows the agents and the environments representing each behaviors characteristic, separately.

The four agents in the model structure include: 1) Ranchers as the main participators in shared activities of livestock husbandry; 2) Government (consisting of legislators, administrators and arbitrators) responsible for legislation, judgment and law enforcement that helps to resolve the conflicts, 3) Government environment sector (natural resources organization) that supports beneficiaries in developing water resources. It also is a reference to handle local violations and 4) Local NGOs as a 
mediator institution pursuing common and legal rights of local people. In the ABM, the environment, in which agents interact and by which their interactions are influenced, is an important component that must be specified. In a natural environment of the case study, drying up of water resources caused by frequent droughts makes environment besides human agents an important factor influencing the participation.

Decisions made by agents, the way agents interact with each other and with the environment in a form of a system, can accelerate or decelerate participation process and ultimately lead to social and ecological stability or instability of beneficiaries and rangelands.

Table 3 shows the breakdowns of factors related to each behavior. These agents in the real world are responsible for the implementation and control of all groups of behaviors.

Table 3. The agents related to the ABM of beneficiaries' participation in managing livestock drinking water in arid rangelands of Yazd Province

\begin{tabular}{|c|c|c|c|c|c|c|}
\hline \multirow{2}{*}{$\begin{array}{c}\text { Identified behavior of ABM of } \\
\text { public participation in } \\
\text { managing livestock drinking } \\
\text { water }\end{array}$} & \multirow[b]{2}{*}{ Symbol } & \multicolumn{5}{|c|}{ Agents and environment } \\
\hline & & $\begin{array}{l}\text { Agent 1: } \\
\text { ranchers }\end{array}$ & $\begin{array}{c}\text { Agent 2: } \\
\text { government }\end{array}$ & $\begin{array}{c}\text { Agent 3: } \\
\text { natural resources } \\
\text { organization }\end{array}$ & $\begin{array}{l}\text { Agent 4: } \\
\text { NGO }\end{array}$ & $\begin{array}{c}\text { Natural } \\
\text { Environment }\end{array}$ \\
\hline $\begin{array}{l}\text { Pursuing common and local } \\
\text { rights of ranchers }\end{array}$ & S1 & & & & • & \\
\hline Poor performance of NGOs & $\mathrm{S} 2$ & & & & • & \\
\hline Low social trust & S3 & & & & • & \\
\hline $\begin{array}{c}\text { Necessity for appropriate } \\
\text { legislation }\end{array}$ & S4 & & $\bullet$ & & & \\
\hline Push for new legislation & S5 & & & & $\bullet$ & \\
\hline Poor performance of promoters & S6 & & & • & & \\
\hline Lack of encouraging motivation & S7 & & $\bullet$ & & & \\
\hline Lack of deterrent penalties & S8 & & $\cdot$ & & & \\
\hline Handling ranchers' violation & S9 & & & • & & \\
\hline Handling the conflicts & S10 & & • & & & \\
\hline Rangelands management styles & S11 & • & & & & \\
\hline $\begin{array}{c}\text { Water resources development } \\
\text { (support action) }\end{array}$ & $\mathrm{S} 12$ & & & • & & \\
\hline $\begin{array}{l}\text { Successive droughts and reduced } \\
\text { rainfall }\end{array}$ & $\mathrm{C} 1$ & & & & & $\bullet$ \\
\hline $\begin{array}{l}\text { Inadequate distribution of water } \\
\text { resources in rangelands }\end{array}$ & $\mathrm{C} 2$ & & & & & • \\
\hline $\begin{array}{l}\text { Low and inadequate income of } \\
\text { ranchers }\end{array}$ & E1 & • & & & & \\
\hline $\begin{array}{l}\text { Financial dependency of ranchers } \\
\text { to the government }\end{array}$ & E2 & $\bullet$ & & & & \\
\hline $\begin{array}{l}\text { Low efficiency of livestock } \\
\text { husbandry in arid rangelands }\end{array}$ & E3 & • & & & & \\
\hline
\end{tabular}

- indicates the agent that is more homogenous and determinant in the related parameter. 


\section{Characteristics of the agents and their interactions}

Identifying key agents and their behavior forms the structure of an agent basedsystem. Various researches in the field of agent-based model have discussed simulating social interactions between agents and the relationship between people and formulating these relations in various social, economic and technical aspects (Akhbari and Grigg, 2015; Bonabeau and Le Page, 2004; Macy and Willer, 2002; Gilbert and Troitzsch, 1999).

As previously mentioned, the methodology of $A B M$ in the initial steps of modeling (i.e. identifying agents and their behaviors, especially in the field of social sciences) has not the necessary transparency. Only a few papers have addressed the identification of key agents in a step before agent based simulation. Therefore, there is a gap in this field. Akbari and Grigg (2015) introduced a general framework in the field of water management for a set of characteristics of agricultural, industrial, domestic/ urban, environmental, recreation, hydropower generation, and regulators agents. In this framework, agents have been compared based on the behavior (reactive, cognitive, hybrid) (Bandini et al., 2009), attributes, rules of behavior, the world of perception (physical, intellectual, emotional, spiritual) (Wolf, 2008), the complexity of decisionmaking (easy, medium, difficult) and flow (Macal and North, 2006a). Reactive agents (e.g. ranchers or NGOs) react based on their perception of stimuli (e.g. the effect of environment or other agents). Cognitive or deliberative agents (e.g. natural resources organs as an environment organization of the state) have more sophisticated selection mechanism than reactive agents. Their behavior is based on their knowledge about environment and the memory of the past experiences. Hybrid agents (e.g. the government) are combinations of reactive and cognitive agents with a layered structure (for more information see Brooks (1986)). Paying attention to the perception of all key actors/ agents is of great importance, because individuals or groups with different perceptions about water issues may have more complexity or difficulty in their participation. Experience has shown that people with rational perception have more tendency to participate than people with emotional perception. Physical and rational perceptions have logical roots; however, spiritual perception has emotional roots. Emotional perception which is based on the values has an emotional root but can also have a logical root (Akhbari and Grigg, 2015). As all the identified agents involved in the management system of livestock drinking water have physical and intellectual perceptions, the possibility of increasing participation seekers is raised. The complexity of decision making of each agent is classified based on the amount of information an agent needs for decision making. Depending on the complexity and the number of factors in each case, decision making can be easy, for example for an NGO agent (pursuing common and legal rights of the ranchers), or can be difficult, for example for government agent, because they have to handle behaviors influencing participation such as legislation, establishing penalties, settling conflicts and providing financial motivation. These features put the government at the center of interactions between the other three features. Table 4 represents the features of agents and interactions between agents for the $\mathrm{ABM}$ of public participation in managing livestock drinking water. The features and behaviors of agents, identified in table 4 are specific to this research, however, for some agents like government, features such as legislation, implementation and judgment are innate/ internal so can be generalized to other issues/studies. In the interactions shown between agents, the government has the most influence on participation which makes ranchers have direct and bilateral interaction with the 
government. Explaining the characteristics of the agents and their interactions with each other and with the environment effectively helps in real understanding of humanenvironment system. In addition it allows the researcher to better understand the social ecological situation of the case study.

\section{Analysis of agents' interaction chain}

After successfully identifying social agents influencing participation, and their behaviors and unique features, the agents interactions with each other and with the natural environment should be examined (Knoeri et al., 2011). Agents chain of interactions is an analysis of how agents are related to other agents, so it leads to the determination of local connection between agents and feedbacks of system's behavior. This step was done based on literature review and participatory interviews (specialized interviews with the experts) (Mieg, 2000). The outcome of this step is a design of a conceptual model of the social-ecological structure of the ABM. We have developed a conceptual model (Fig. 1) which represents the problem of poor participation in managing livestock drinking water of arid rangelands of Yazd. In this model, the interactions of 4 agents of ranchers, government, NGOs and natural resources organ with each other and with the environment are shown. Each agent in this model can affect other agents and thus the output of the system through the decisions they make.

Behavioral interactions of the agents depends on the type of finalized behavior and the effectiveness of each behavior is determined by the effectiveness coefficient obtained from the analytical network process (ANP) which is described in the next step. Considering the bilateral relations of behaviors and consequently that of agents, using ANP greatly helps us in identifying the system and analyzing the outputs. 


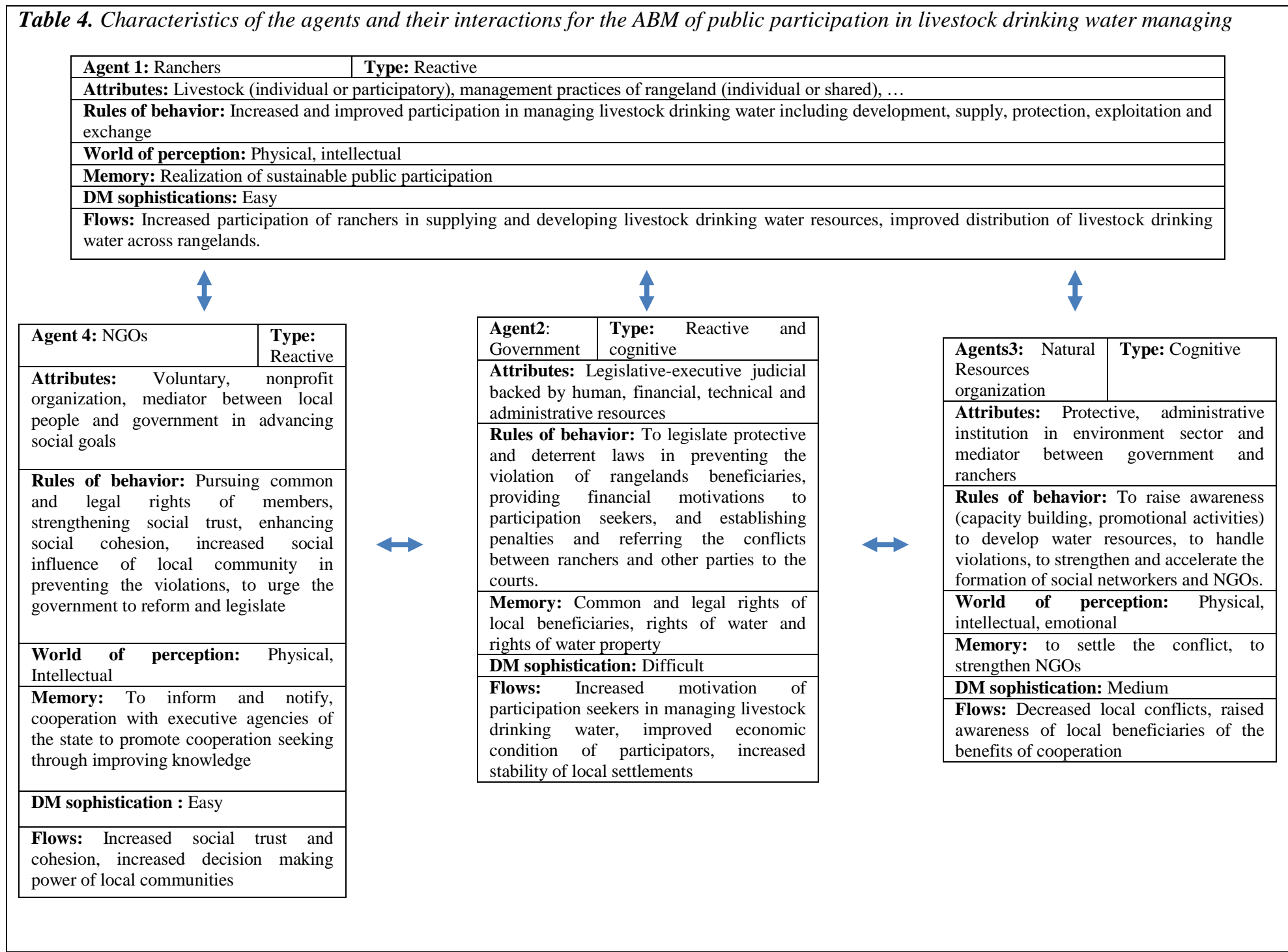




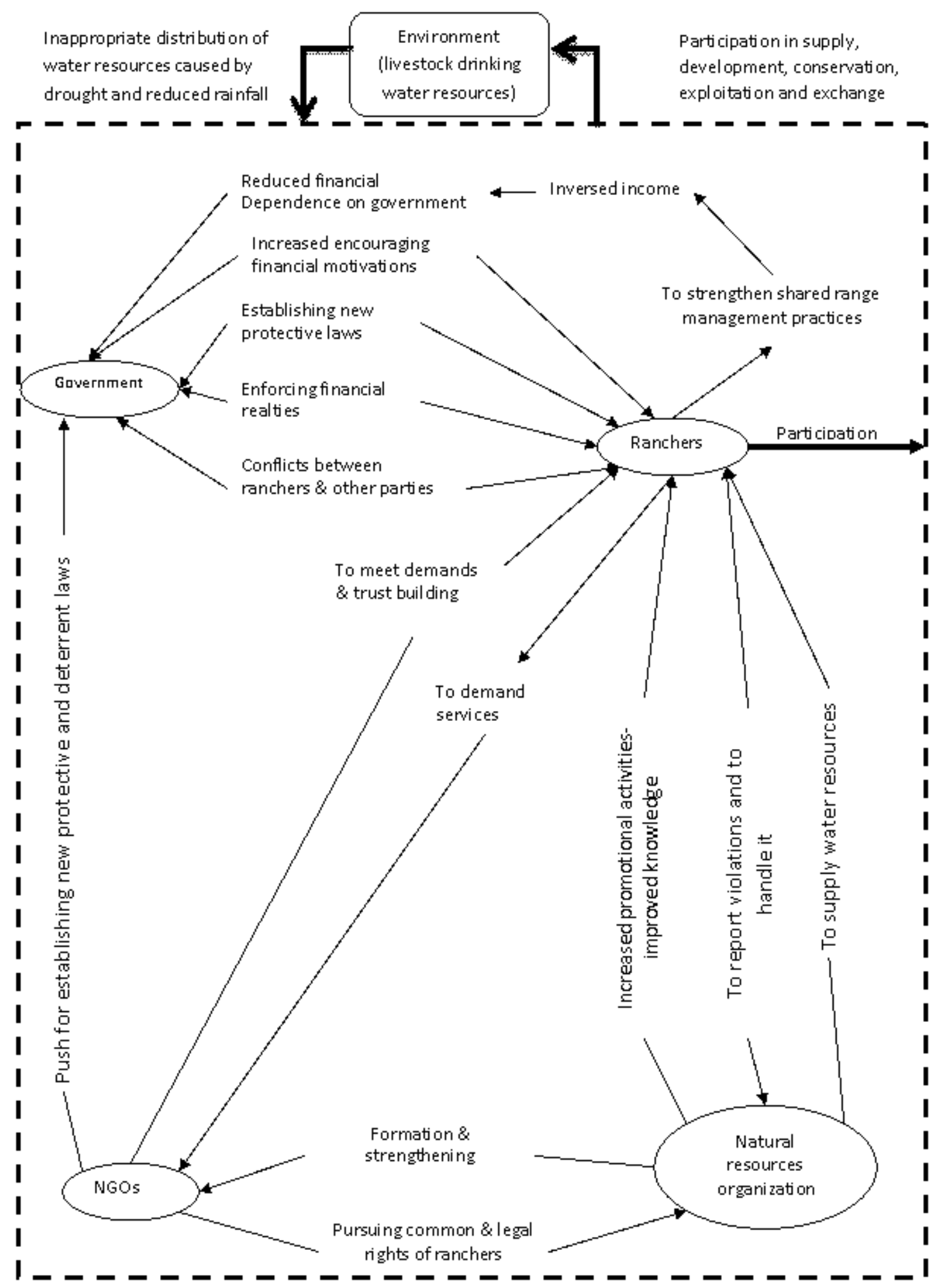

Figure 1. Socio-ecological structure of participation for livestoke drinking water resource management based on $A B M$ 


\section{Quantification of the agents' decision-making process}

This step is aimed at forming a network structure of decision items and quantifying and prioritizing them. This step is going to identify the relation between criteria (as a category of decision elements) and behavioral alternatives, determined in the step 2, in the form of a network. In the recent years, Multi Criteria Decision - Making (MCDM) methods have been taken into consideration for evaluating and selecting the best criteria and effective options in a managerial and complex phenomenon.. In the present research the Analytical Network Process was used, because the dependence of criteria (economic, social and climatic) and the behaviors were not linear but mutual with feedbacks (Saaty, 1999). In this case, weights of criteria depend on behaviors (defined as "alternatives" in the software) and weights of behaviors depend on criteria. For this reason, using ANP instead of AHP in most fields has been increased in recent years (Jharkharia and Shankar, 2007). ANP model is very much like AHP model which includes the steps of formation of clusters, nodes, developing relations between criteria and alternatives (internal and external dependency) taken place in order to build a network . Finally, weighting the criteria and alternatives is done to prioritize the behaviors. The research done by Saaty (Saaty and Takizawa, 1986) is one of the pioneering works in the field ANP. Some ANP applications include: designing executable models of artificial intelligence systems (Lin et al., 2009), improving energy usage in railroad transportations (Chang et al., 2009), choosing new export markets (Buitrago and Lesmes, 2010), predicting car sales (Mimovic, 2012) and risk assessment in producing renewable energy form agricultural biomass (Rivza et al., 2013). The experts' judgments were used in determining types of relations and weighting. In ANP, measuring the relative importance is performed like AHP which is based on paired comparison and a range of 1 to 9. Level 1 represents equal importance of two behaviors and 9 represents strong importance of one behavior compared to another. Superdecision software was used to analyze the large dataset of the research fast and accurately. Fig. 2 shows the structure of the designed network in this software. Three levels were considered in this structure. The first level is the target level. The second level is the level in which social, economic and climatic criteria are categorized and their interactions are specified. In the third level, behaviors are placed separately in the alternatives part. Interdependencies between behaviors have been applied in this level. In the case of using unidirectional relation of AHP, the model is not expected that criteria and alternatives have mutual relations and dependences.

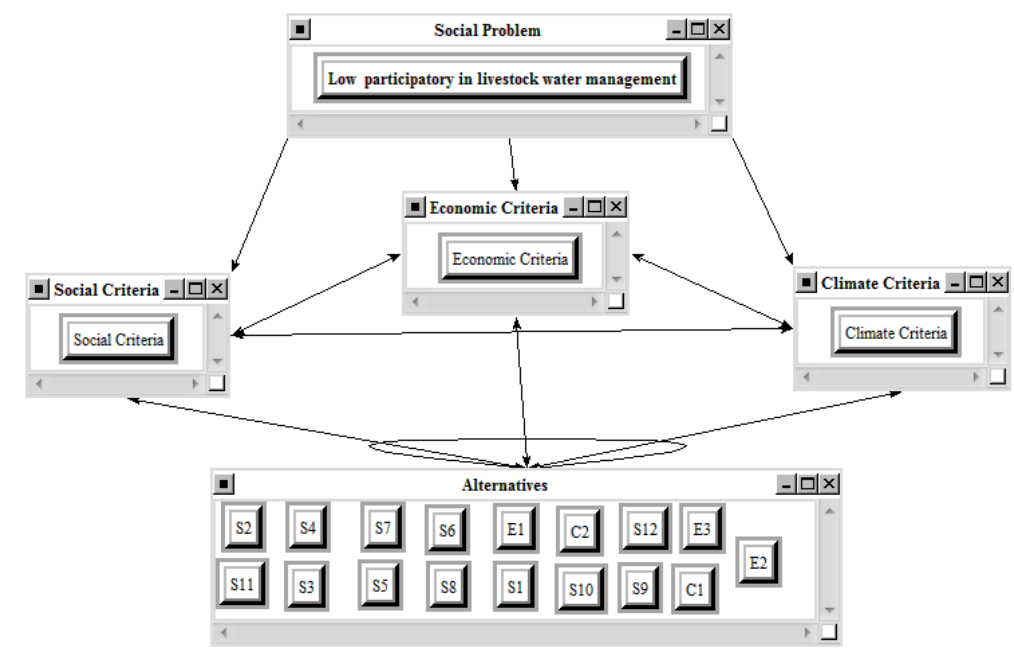

Figure 2. Structure of designed network in the superdecisions software 
Therefore the designed model prioritizes behaviors influencing the problem of poor public participation more accurate and more reliable than AHP. Fig. 3 represents the results and final synthesis of ANP.

The ranking of various alternatives (identified behaviors) have been shown in this figure. Fig. 3 shows that the main criterion in poor participation of people in the research area is the economic (livelihood problem of livestock beneficiaries). Low and inadequate income of ranchers makes them financially dependent on the government so they have low motivation for participation.
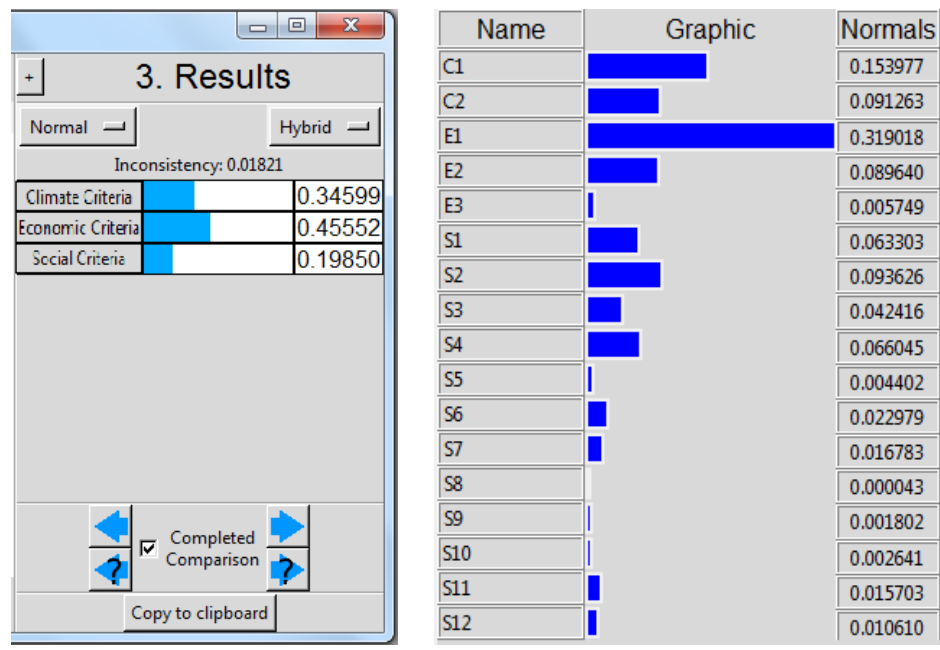

Figure 3. The results and final synthesis of ANP

Now it can be said with more certainty that, the three main parameters leading to poor participation of livestock beneficiaries respectively include: 1) low income of livestock beneficiaries in Yazd (E1) with normal weight of 0.319, 2) Successive draughts and reduced rainfall in the research area $(\mathrm{C} 1)$ with normal weight of $0.153,3$ ) poor role of NGOs (S2) with normal weight of 0.093. This step of agent - based modeling helped in more accurately analyzing the problem of poor public participation and providing more accurate information for the decision - makers of natural resources.

\section{Model validation}

In this research, all steps, from identifying the agents to ANP discussion, were done based on specialized interviews with local experts and professionals (academic and executive). Experts were the professionals with experience and knowledge about the area under research. Moreover, strict criteria were applied so that the most effective behaviors were chosen. This allows us to test the assumptions made in each step of the model development procedure leading to the conceptual model and, therefore, to ensure the validity of the conceptual model (Knoeri et al., 2011; Sargent, 2008). The conceptual validation of model requires that the theories and assumption in the decision - making model are correct, and thus the model reflects the behaviors (Knoeri et al., 2011): the assumption of selecting analytical network as a multi - criteria decision making method for the problem of the research was that ANP considers external dependency (e.g. interactions between criteria) and internal dependency (e.g. 
interactions between behaviors). In the present research, the identified behaviors are not independent of each other, but the results of the impacts of each other and the surrounding environment. For example lack of protective rules leads to reduced motivation of participators which consequently reduced the participation. Hence, ANP method was a good choice and conceptual validation was met. Given that the conceptual validation of model was confirmed, which was so important, thus the validation of the agent - based model is also confirmed (Knoeri et al, 2011).

\section{Conclusions}

This research aimed to achieve an executable solution for the management of livestock drinking water in Yazd rangelands through assessing the environment-human system influencing participation and using ABM approach to solve the complex problem of poor participation. Identifying key actors (agents), behavior rules, and characteristics of the agents in this system, which led to the design of the socialecologic structure, were some parts of the complexity. The participation concept in this research is a multi-dimensional phenomenon which is formed as a result of emergent behaviors of policy making and legislation agents, natural resources organization as the governmental sector, NGOs and livestock beneficiaries. Simple behavior rules resulted from the combined activities and motivations of various agents form patterns feedbacks influencing participation decisions and individuals' choices. To solve this complex problem, this research used the Delphi technique which was based on the consensus of a group of experts. This research has taken advantages of inherent flexibility of the technique to collect and analyze data and to document the process of the research. Outstanding features of the Delphi technique in decision-making helped in providing an operational agent-based model. This model presents a through understanding of the present actors (agents), their interactions and behaviors, which can improve participation, and will be a solution for decision - makers to solve the problem of poor participation. Another major goal of this research was to compensate for the model's shortcoming of being theoretical merely. This was achieved through a step - wise approach. Attempts were made to overcome the ABM limitation (including being theoretical, non - real agents, and validation of the ABM model) by providing a transparent and efficient methodology. Stepwise identification of the agents and behaviors using the Delphi technique led to four agents and 15 behaviors. In step two (analysis of agents' interaction chain) a social - ecological structure influencing the case research was designed. In this model, interactions of four agents of policy makers and legislators, natural resources organization, livestock beneficiaries and NGOs with their behaviors resulted in influencing each other and changing human participation in management project of livestock drinking water. In step three, quantifying the elements of decision (criteria \& behaviors) using ANP model not only provided decision making data but also provided an opportunity to test decision - making hypothesis. Among other MCDM models, the ANP was chosen and used because social, climatic and economic criteria influencing the participation were not independent and this model could overcome the limitation of the AHP approach which was the assumption of independency between criteria and alternatives. This research also identified the interrelationships between behaviors that allowed a proper assessment. Validation of the conceptual hypotheses through an experimental test (ANP), improved the validity of conceptual model too. The results of prioritization of the criteria show that the economic 
criterion has greater effect on the participation of local communities in Yazd Province compared to the other two criteria (i.e. climate and social). It was found in this research that the most important problem which livestock beneficiaries were facing was the economic issues especially low income of ranches and their financial dependency on the government. A critical social problem found in this research was the local conflicts weakening social trust between beneficiaries. This was due to the fact that, strong NGOs with the mechanisms of reinforcing the bonds of trust either did not exist or were inefficient. Another fact in the area under study was that the participation system was influenced by the environmental conditions and thus reduced the motivation of major actors (livestock beneficiaries) in interacting with other agents. In line with developing water resources and providing financial supports, attempts were made by government and natural resources organization in reducing the effects of drought which are of great importance. Given the increasing functions of these two important actors in participation system, there was a hope that the weakened factor of social trust, linking participation agents, would be strengthened. Modeling with the defined methodology in this research simplified our scientific understanding of the reality and improved our sociological insights into the reality. Todays, modeling social interaction is helpful in solving many complex social - ecological issues and this research is an example of solving these kinds of problems using an agent - based model that can be expanded to other similar participation systems.

\section{REFERENCES}

[1] Akhbari, M., Grigg. N. S. (2013): A framework for an agent-based model to manage water resources conflicts. - Water resources management 27(11): 4039-4052.

[2] Akhbari, M., Grigg. N. S. (2015): Managing Water Resources Conflicts: Modelling Behavior in a Decision Tool. - Water Resources Management 29(14): 5201-5216.

[3] Arnold, J.S., Gimenez, M. (2007): Building social capital through participatory research: An analysis of collaboration on Tohono O'odham tribal rangelands in Arizona. - Society and Natural Resources 20(6): 481-495.

[4] Azarnivand, H., Zare Chahoki, M. A. (2008): Range Improvement. - Tehran University Press: Tehran. (In Persian).

[5] Bandini, S., Manzoni, S., Vizzari, G. (2009): Agent Based Modeling and Simulation: An Informatics Perspective. - JASSS 12: A51-A66.

[6] Binder, C.R. (2007): From material flow analysis to material flow management Part II: The role of structural agent analysis'. - Journal of Cleaner Production 15:1605-1617.

[7] Bonabeau, E. (2002): Agent-based modeling: methods and techniques for simulating human systems. - Proc Natl Acad Sci 99(suppl 3): 7280-7287.

[8] Bond, J. (2014): A holistic approach to natural resource conflict: The case of Laikipia county, Kenya. - Journal of Rural Studies 34: 117 - 127.

[9] Bousquet, F. Le Page, C. (2004): Multi-agent simulations and ecosystem management: a review. - Ecological Modelling 176: 313-332.

[10] Brooks, RA. (1986): A Robust Layered Control-System for a Mobile Robot. - Ieee T Robotic Autom 2:14-23.

[11] Buitrago, L., Lesmes, D. (2010): Application of analytical network process (ANP) to select new foreign markets to export software services: study of colombian firms. Escenarios 8(1): 25-36.

[12] Bulger, S.M., Housner, L.D. (2007): Modified Delphi investigation of exercise science in physical education teacher education. - J Teach Phys Edc 26:57-80. 
[13] Cedermann, L.E. (2005): Computational models of social forms; advancing generative process theory'. - American Journal of Sociology 110 (4): 864-893.

[14] Chang, Y. H., Way, W. M., Tseng, H.Y. (2009): Using ANP priorities with goal programming for revitalization strategies in historic transport: a case study of the Alishan forest railway. - Journal of Expert Systems and Application 36: 8682-8690.

[15] Delbecq, A.L.,,Van de Ven, A., Gustafson, D. (1975): Group Techniques for Program Planning: A Guide to Nominal Group and Delphi Processes. - Glenview, IL: Scott, Foresman, and Company.

[16] Francis, E., Opiyo, O., Stephen, M., Mureithi, R., Ngugi, K. (2011): The Influence of Water Availability on Pastoralist's Resource Use in Mwingi and Kitui Districts in Kenya. - J Hum Ecol 35(1): 43-52.

[17] Gezon, L. (1997): Institutional structure and the effectiveness of integrated conservation and development projects: Case study from Madagascar. - Human Organization 56 (4): 462- 470.

[18] Giddens, A. (1984): The Constitution of the Society. - Berkeley, CA: University of California Press.

[19] Gilbert, N., Troitzsch, K.G. (1999): Simulation for the social scientist. - Open University Press, Buckingham.

[20] Gilbert, N., Troitzsch, K.G. (2005): Simulation for the social scientist. (2 edition.).Berkshire, England: Open University Press, McGraw-Hill.

[21] Gordon, T.J. (1992): The methods of futures research [Electronic version]. -Annals Am Academy Political Soc Sci 522: 25-36.

[22] Hanemann, M., Dyckman, C. (2009): The San Francisco Bay-Delta: a failure of decisionmaking capacity. - Environ Sci Policy 12(6):710-725.

[23] Hasson, F., Keeney, S., McKenna, H. (2000): Research guidelines for the Delphi survey technique. - J Adv Nurs 32(4):1008-1015.

[24] Islami, I., Abdollahian, H. (2016): Measuring social capital and analyzing social structure of participation and trust: Network of local livestock beneficiaries in center of Iran, The Social Sciences, 11(27): 6617-6627.

[25] Islami, I., Ghorbani, M., Jafari Shalamzari, M. (2013): Identification and prioritization of factors influencing agricultural water price index from farmers' viewpoint in Charkhab Village, Yazd Province. - DESERT 17: 161-167.

[26] Islami. I., Sadoddin., A. (2014): Economic value of water in arid regions: Greenhouse culture application. - Proceeding of the Second International Conference on Sustainable Watershed Management (SUWAMA 14), Turkey, CRC Press, pp. 201 - 208.

[27] Jager, W. Janssen, M. (2002): The need for and development of behaviourally realistic agents'. - In: Sichman, J. S., Bousquet, F., Davidsson, P. (eds.) 3rd International Workshop on Multi-Agent-Based Simulation II (MABS 2002). Bologna, Italy: SpringerVerlag Berlin: 36-49.

[28] Janssen, M.A. (2002): Complexity and ecosystem management: the theory and practice of multi agent systems. - Cheltenham: Elgar.

[29] Janssen, M.A., Ostrom, E. (2006): Empirically based, agent-based models'. - Ecology and Society 11: 2 .

[30] Jeffery, G., Hache, G.A. (1995): A group-based Delphi application: Defining rural career counseling needs. - Measurement Evaluation Counseling Devlp 28(1):45-61.

[31] Jharkharia, S., Shankar, R. (2007): Selection of logistics service provider: An analytic network process (ANP)". - Omega 35(3): 274-289.

[32] Keeney, S., Hasson, F., McKenna, H. (2006): Consulting the oracle: ten lessons from using the Delphi technique in nursing research. - J Adv Nurs 53(2):205-212.

[33] Keshavarz, M., Karami, E., Vanclay, F. (2013): The social experience of drought in rural Iran. - Land Use Policy 30: 120- 129. 
[34] Knoeri, C., Binder, C.R., Althaus, H.J. (2011): An Agent Operationalization Approach for Context Specific Agent-Based Modeling. - Journal of Artificial Societies and Social Simulation 14 (2): 4.

[35] Lin, Y.H., Tsai, K.M., Shiang, W.J., Kuo, T.C., Tsai, C.H. (2009): Research on using ANP to Establish a performance assessment model business intelligence systems. Journal of Expert System and Applications 36(2): 4135-4146.

[36] Macal, C.M., North, M.J. (2006): Tutorial on agent-based modeling and simulation part 2: how to model with agents. - Proc. of 2006 Winter Simulation Conference, 73-83.

[37] Macal, C.M., North, M.J. (2006b): Tutorial on agent-based modeling and simulation Part 2: How to model with agents. - Proceedings of the 2006 Winter Simulation Conference, Monterey, CA.

[38] Macy, M.W.,Willer, R. (2002): From factors to actors: Computational sociology and agent based modeling. - Annual Review of Sociology 28: 143-66.

[39] Matthews, R.B., et al. (2007): Agent-based land-use models: a review of applications'. Landscape Ecology 22 (10).

[40] Meier, P., Bond, D., Bond., J. (2007): Environmental influences on pastoral conflict in the Horn of Africa. - Political Geography 26: 716-735.

[41] MENARID. (2015): International Project Newsletter, No. 8.

[42] Mieg, H.A. (2000): University-based projects for local sustainable development: Designing expert roles and collective reasoning'. - International Journal of Sustainability in Higher Education 1: 67-82.

[43] Mimovic, P. (2012): Application of analytical network process in forecasting automobile sales of FIAT 500L. - Econimic Horizons 14(3): 169-179.

[44] Mosler, H.J., Tobias, R. (2005): Simulation of collective action based on empirical data', 2nd International Conference of the European Social Simulation Association (Valladolid, Spain).

[45] O'Faircheallaigh, C. (2010): Public Participation and environmental impact assessment: Purposes, implications, and lessons for public policy making. - International Journal by Environmental Impact Assessment Review 30: 19-27.

[46] Parentè, F.J, Anderson-Parentè, J. (1987): Delphi inquiry systems. - In: Wright, G., Ayton, P. (eds.) Judgmental Forecasting. New York, NY: John Wiley \& Sons 1987:129156.

[47] Parker, D.C., Manson, S.M., Janssen, M.A., Hoffmann, M.J., Deadman, P. (2003): Multiagent systems for the simulation of land-use and land-cover change: a review. - Ann Assoc Am Geogr 93(2):314-337.

[48] Piran., P. (2005): Water conflicts and Conflict management mechanisms in middle east and north Africa region: The case of Iran the world bank, CEDARE, Cairo [web.cedare.org/wp-content/uploads/2017/03/Water-Conflicts.pdf]

[49] Rishi, P. (2003): Joint forest management in India: An attitudinal analysis of stakeholders. - Resources, Conservation and Recycling 51(2): 345-354.

[50] Rivza, S., Pilvere, I., Rivza, P., Rivza, B. (2013): The use of analytical network process for risk assessment in production of renewable energy from agriculture biomass in Latvia. - Journal of Systemic, Cybernetics and Informatics 11(1): 66-72.

[51] Saaty T. L., Takizawa, M. (1986): Dependence and independence: From linear hierarchy to nonlinear networks. - European Journal of Operational Research 26(2): 229-237.

[52] Saaty, T.L. (1999): Fundamentals of the Analytic Network Process". - Proceedings of ISAHP 1999, Kobe, Japan.

[53] Sandrey, M.A., Bulger, S.M. (2008): The Delphi Method: An Approach for Facilitating Evidence Based Practice in Athletic Training. - Athletic Training Education Journal 3(4):135-142.

[54] Sargent, R.G. ( 2008): Verification and validation of simulation models'. - 2008 Winter Simulation Conference (Washington, DC): 112-125. 
[55] Selby, J., Hoffmann, C. (2014): Beyond scarcity: Rethinking water, climate change and conflict in the Sudans. - Global Environmental Change. 29:360-370 https://doi.org/10.1016/j.gloenvcha.2014.01.008

[56] Semsaryazdi , A.A., Labbaf Khaneiki, M. (2007): The drought of 2001and the measures taken by Yazd regional water authority. - Proceedings of the International Workshop, Groundwater for emergency situations, Tehran, 29-31 October 2006, IHP/2007/GW-15UNESCO.

[57] Skulmoski G.J., Hartman, F.T., Krahn, J. (2007): The Delphi Method for graduate research. - J Info Tech Edc 6: 1-21.

[58] Squazzoni, F. (2012): Agent-Based Computational Sociology. - WILEY, ISBN: 978-0470-71174-3 - 256 pages, UK.

[59] Turner, M.D. (2004): Political ecology and the moral dimensions of "resource conflicts": the case of farmer-herder conflicts in the Sahel. - Political Geography 23:863-889.

[60] Vicente, P., Reis, E. (2008): Factors influencing households' participation in recycling. Waste Management and Research 26(2): 140-146.

[61] Wilensky, U., Rand, W. (2015): An Introduction to Agent-Based Modeling: Modeling Natural, Social, and Engineered Complex Systems with NetLogo. - MIT Press.

[62] Ziglio, E. (1996): The Delphi Method and its contribution to decision-making. - In: Adler, M., Ziglio, E. (eds.) Gazing into the Oracle: The Delphi Method and its Application to Social Policy and Public Health. Bristol, PA: Jessica Kingsley Publisher 1996:3-33. 